\title{
WOODLANDS IN AGRICULTURE
}

\section{The Management of Farm Woodlands}

By Cedric H. Guise. (American Forestry Series.) Pp. $x+352$. (New York and London: McGrawHill Book Co., Inc., 1939.) $20 s$.

$\mathrm{A}^{\mathrm{T}}$ T the outset, farm woodlands are defined as areas of wooded growth that are integral parts of the lands used primarily for agriculture. As such they serve various useful purposes in affording protection to buildings and stock, in preventing undue soil erosion and, if skilfully managed, in providing profitable timber of various types. The problems of agriculture and forestry are inseparable in regions where the better soils are utilized for crop-growing and pastures, and woodland occupies the area of poorer quality. Detailed tables show how widespread these woodland areas are in the United States, the total value of the produce used and sold therefrom amounting to 190 million dollars per annum.

Good management of woodland entails the adherence to a definite policy based on sound technical forestry methods. Much improvement can be effected by judicious cutting, ranging from the provision of small wood for domestic purposes to the taking out of mature timber. In this, care is necessary to prevent injury to other trees from decreasing future profits. A management plan and simple book-keeping for each parcel of wood, com- bined with adequate selling arrangements form the basis of profitable woodland cultivation.

The volume under review is essentially a practical exposition of the knowledge and methods required to render the woodland a profitable section of the farm economy. The outline of woodland ecology describes the various types of growth, the light and temperature requirements of different species, and their susceptibility to diseases and pests, and provides lists of the most important trees associated with certain areas. A valuable section deals with methods of determining the volume, increment and yield of woodland products and the production of surveys and maps. Under the heading of protection the damage done to trees by grazing is emphasized, since usually a wood has little real value as a source of food for grazing animals, and both animals and woodland are likely to suffer.

Chapters on the utilization and marketing of woodland products, the durability and preservation treatment of wood and the general principles of management round off a book which should prove of great value to sylviculturists in all parts of the world. While the theme is woodlands in the United States, the text is of much wider application, and should be read with profit by all who are interested in the full utilization of all types of agricultural land. W. E. BRENCHLEY.

\section{COLOUR AND MUSIC}

Colour Co-ordination

By M. Sargant-Florence. Pp. 352. (London : John Lane, The Bodley Head, Ltd., 1940.) 15s. net.

$\mathrm{M}$ ANY years ago, McDougall suggested that much confusion of thought on the subject of perception would have been avoided if all philosophers had been born blind. To this we might add that it would have been well if all colourists had been born deaf; and we might even begin to wish that Newton had never been born at all.

To such heresies are we driven by this book on colour co-ordination, which is devoted to establishing a theory of colour harmony by analogy to the theory of harmony in music, an idea which originated in the main from Newton. In his day, practically nothing was known of the mechanism of colour perception, and in the nature of things his suggestion could have been little more than a guess. The truth is that, even at the present day, our knowledge of the colour processes is so imperfect that it is quite impossible to say why some colours harmonize and others clash.

No one will grudge artists their attempt to establish an arbitrary system of colour harmony, although some of us may wonder why they should need it, and we may suspect that the greatest artists have done quite well without it. We would, however, admit that in teaching the less gifted among us, a system is useful, although its limitations may be dangerous. If we can assume that those with artistic leanings are likely to be conversant with musical theory, there is even something to be said for choosing music as the analogy. The real grievance of the man of science is different. What he must object to is the attempt to bolster up any analogy with pseudo-scientific ideas that must inevitably mislead those who have had no scientific training.

Newton's idea was based essentially on the 